\title{
Cost of Illness pada Pasien Diabetes Melitus dengan Diabetic Foot: Systematic Review
}

Alvina Dewi Astuty ${ }^{1}$, Gusti Noorizka Veronika Achmad ${ }^{2} *$ Yunita Nita $^{2}$ Lestiono $^{3}$

${ }^{1}$ Fakultas Farmasi, Universitas Airlangga, Surabaya, Indonesia

${ }^{2}$ Departemen Farmasi Praktis, Fakultas Farmasi, Universitas Airlangga, Surabaya, Indonesia

${ }^{3}$ Rumah Sakit Pusat Angkatan Laut dr. Ramelan Surabaya

*Corresponding author: gusti-n-v-a@ff.unair.ac.id

Submitted: 10 November 2020

Accepted: 31 December 2020

Published: 09 April 2021

\begin{abstract}
Background: Diabetes mellitus (DM) is one of the leading causes of death from non-communicable disease in the world. Diabetes can cause further complications if the patient does not comply with the therapy given, one of them is diabetic foot. DM with diabetic foot complication brings huge economic losses. Objective: This study aims to determine the cost of illness in DM patients with diabetic foot. Methods: This research using PRISMA statement which was conducted in April - July 2020. The search for articles was searched on the Pubmed, Cochrane, Sciencedirect, Scopus, and Ebscohost using PICO to determine the keywords. Results: From the seven articles that were included in this study, it was found that the total costs generated varied from 2341.63 USD/year to 20977.56 USD/year for patient perpective, 2703.24 USD/year to 8790.41 USD/year and 8129.96 USD/episode for hospital perpective, and 2144.21 USD/episode and 14819.78 USD/year for perpective third payer. The majority of research uses retrospective and hospital perspective. The most calculated costs are direct medical costs with costs reaching $51.7 \%$ to $98.4 \%$ of the total costs incurred for the treatment. Meanwhile, the cost spent on treatment for DM patients with diabetic foot is two to four times greater than DM patients without diabetic foot with the percentage of costs for complications of diabetic foot alone reaching $55.9 \%$ to $71.7 \%$ of the total costs incurred. Conclusion: DM patient with diabetic foot spend more resources that increase costs of treatment compared to DM without diabetic foot.
\end{abstract}

Keywords: cost of illness, diabetes mellitus, diabetic foot, systematic review

\begin{abstract}
Abstrak
Pendahuluan: Diabetes melitus (DM) merupakan salah satu penyebab kematian akibat penyakit tidak menular terbesar di dunia. Diabetes dapat menyebabkan komplikasi lebih lanjut jika pasien tidak patuh dalam menjalani terapi yang diberikan, salah satunya yaitu diabetic foot. DM dengan diabetic foot membawa kerugian ekonomi yang besar. Tujuan: Penelitian ini bertujuan untuk dapat mengetahui cost of illness pada pasien DM dengan diabetic foot dengan systematic review. Metode: Penelitian ini dilakukan dengan metode systematic review dengan menggunakan PRISMA statement yang dilakukan pada bulan April - Juli 2020. Pencarian artikel dilakukan pada Pubmed, Cochrane, Sciencedirect, Scopus, dan Ebscohost dengan menggunakan PICO hingga pada tanggal 22 Juli 2020 dengan kriteria inklusi yaitu studi terkait cost of illness, subyek penelitian merupakan pasien diabetic foot, dan artikel memuat hasil penelitian berupa cost dari diabetic foot untuk menentukan kata kunci yang akan digunakan. Hasil: Dari hasil tujuh artikel didapatkan bahwa total beban biaya yang dihasilkan yaitu 2341,63 USD/tahun hingga 20977,56 USD/tahun untuk perspektif pasien, 2703,24 USD/tahun hingga 8790,41 USD/tahun dan 8129,96 USD/episode untuk perspektif rumah sakit, serta 2144,21 USD/episode dan 14819,78 USD/tahun untuk perspektif pembayar pihak ketiga. Mayoritas penelitian menggunakan metode pengambilan data retrospektif dan bottom-up, sedangkan untuk perspektif yang paling banyak digunakan adalah perspektif rumah sakit. Biaya yang paling banyak dihitung adalah direct medical cost dengan biaya yang dihabiskan mencapai $51,7 \%$ hingga $98,4 \%$ dari total keseluruhan biaya. Lalu biaya yang dihabiskan untuk
\end{abstract}


pengobatan untuk pasien DM dengan diabetic foot mencapai dua hingga empat kali lebih besar daripada pasien DM tanpa diabetic foot dengan persentase biaya untuk komplikasi diabetic foot mencapai 55,9\% hingga 71,7\% dari total biaya yang dikeluarkan. Kesimpulan: Pasien DM dengan diabetic foot menghabiskan lebih banyak sumber daya sehingga meningkatkan biaya pengobatan dibandingkan dengan DM tanpa diabetic foot.

Kata kunci: cost of illness, diabetes melitus, diabetic foot, systematic review

\section{PENDAHULUAN}

Sustainable Development Goals (SDGs) atau Tujuan Pembangunan Berkelanjutan merupakan suatu rencana aksi global yang disepakati oleh para pemimpin dunia, termasuk Indonesia, untuk mengakhiri kemiskinan, mengurangi kesenjangan, dan melindungi lingkungan yang diharapkan dapat dicapai pada tahun 2030. Salah satu target dari SDGs yaitu mengurangi hingga sepertiga angka kematian dini akibat penyakit tidak menular (PTM) (INFID, 2017). Pada tahun 2015, tercatat $70 \%$ kematian di dunia diakibatkan oleh PTM dan 80\% diantaranya termasuk diabetes melitus (DM) (IDF, 2017; WHO, 2018). Menurut data dari International Diabetes Federation (IDF) pada tahun 2017, terdapat 444,9 juta penduduk di dunia yang menderita penyakit DM dan Indonesia menduduki peringkat ke enam di dunia dengan jumlah penduduk yang menderita penyakit DM sebesar 10,3 juta penduduk (IDF, 2017). Hal ini diakibatkan oleh budaya negara Indonesia yang memiliki pola makan masyarakatnya yang banyak mengkonsumsi nasi sebagai makan pokok dan makan makanan cepat saji. Nasi yang termasuk dalam karbohidrat dapat menyebabkan naiknya gula dalam darah seseorang sehingga dapat berakibat orang tersebut berpotensi untuk menderita DM di kemudian hari, sedangkan makanan siap saji memiliki kandungan kalori 23\% lebih besar daripada makanan rumahan (Balasegaran, 2006). Menurut hasil dari Riskesdas pada tahun 2018, prevalensi penderita DM di Jawa Timur sebesar 2,02\% dan di Surabaya sebesar 3,5\% (Kemenkes RI, 2018).

DM merupakan suatu kelompok penyakit metabolik dengan karakteristik hiperglikemia yang terjadi karena kelainan sekresi insulin, kerja insulin atau kedua-duanya (PERKENI, 2015). Menurut panduan American Diabetes Association (ADA), terapi untuk DM dikategorikan menjadi terapi nonfarmakologi dan farmakologi. Terapi non-farmakologi meliputi diet dan olahraga. Sedangkan untuk terapi farmakologi digunakan obat oral antidiabetes dan insulin (ADA, 2019; Triplitt dkk., 2016).
Diabetes dapat menyebabkan komplikasi lebih lanjut jika pasien tidak patuh dalam menjalani terapi yang diberikan. Terdapat 2 jenis komplikasi, yaitu komplikasi makrovaskular dan mikrovaskular. Komplikasi makrovaskular termasuk penyakit jantung koroner, stroke, dan penyakit pembuluh darah perifer. Komplikasi mikrovaskular termasuk retinopati, neuropati, dan nefropati (Schwinghammer, 2015). Komplikasi yang diakibatkan berkurangnya aliran darah di perifer dan neuropati di kaki dapat meningkatkan kemungkinan terjadinya diabetic foot pada penderita DM (ADA, 2019; WHO, 2018).

Diabetic foot adalah komplikasi diabetes kronis yang terdiri dari lesi pada jaringan dalam yang berhubungan dengan gangguan neurologis (neuropati) dan penyakit pembuluh darah perifer pada tungkai bawah (Zhang dkk., 2017). Prevalensi rata-rata orang yang menderita diabetic foot adalah $6,4 \%$ di dunia (IDF, 2017). Sedangkan di Indonesia prevalensi diabetic foot pada tahun 2016 adalah 12\% (Yusuf dkk., 2016). Angka kejadian diabetic foot pada pria lebih banyak dibandingkan wanita. Serta, lebih sering terjadi pada pasien DM tipe 2 daripada pasien DM tipe 1 (Zhang dkk., 2017). Untuk mengobati diabetic foot yang dialami oleh pasien maka perlu adanya tindakan dan terapi yang harus dilakukan.

Tindakan dan terapi untuk diabetic foot meliputi penanganan iskemia, debridemen, penanganan luka, menurunkan tekanan plantar pedis (offloading), penanganan bedah, penanganan komorbiditas dan menurunkan risiko kekambuhan serta pengelolaan infeksi (Langi, 2013; Singh dkk., 2013). Beberapa metode offloading antara lain total non-weight bearing, total contact cast, foot cast dan boots, sepatu yang dimodifikasi (half shoe, wedge shoe), serta alat penyangga tubuh seperti cruthes dan walker (Langi, 2013). Selain itu, ada juga terapi adjuvan lain yaitu terapi oksigen hiperbarik, pemberian granulocyte colony stimulating factors dan faktor pertumbuhan, serta bioengineered tissue (Langi, 2013; Singh dkk., 2013). Tindakan dan terapi yang dijalani oleh pasien 
Jurnal Farmasi Dan Ilmu Kefarmasian Indonesia

Special Issue: Seminar Inovasi Teknologi Dan Digitalisasi Pada Pelayanan Kefarmasian 2020

dapat menimbulkan biaya yang besar pada pasien DM dengan diabetic foot.

DM dengan diabetic foot membawa kerugian ekonomi yang besar, baik bagi pasien dan keluarga serta bagi negara. Total biaya yang dikeluarkan untuk pengobatan DM sendiri di dunia menurut IDF yaitu sebesar 727 miliar USD pada tahun 2017 untuk usia 20-79 tahun dan di Indonesia sebesar 120,3 miliar USD pada tahun 2017 (IDF, 2017). Sedangkan biaya yang dikeluarkan pasien DM dengan diabetic foot (296 USD) lebih besar hingga 4 kali lipat pasien DM tanpa diabetic foot (69,91 USD) (Raghav dkk., 2018).

Berdasarkan data biaya yang ditimbulkan oleh DM dengan diabetic foot tersebut maka perlu dilakukan penelitian cost of illness (COI) yaitu penelitian yang dilakukan untuk menghitung beban ekonomi yang ditimbulkan dari suatu penyakit atau gangguan. Untuk melakukan penelitian COI maka diperlukan perspektif penelitian untuk menentukan biaya apa saja yang akan dihitung (Rascati, 2014). Perspektif adalah cara pandang terhadap suatu masalah yang terjadi, atau sudut pandang tertentu yang digunakan dalam melihat suatu fenomena (Martono, 2012).

Penelitian ini dilakukan dengan systematic review yaitu suatu penelitian ilmiah dengan metode yang telah ditentukan, dalam penelitian digunakan PRISMA statement. Di dalam PRISMA statement dijelaskan langkah - langkah untuk melakukan systematic review, mulai dari pencarian data artikel, screening artikel, menyeleksi eligibilitas artikel, dan menentukan artikel yang terpilih. Untuk mendapatkan data artikel digunakan kata kunci yang sebelumnya telah ditentukan dengan PICO dan dicari menggunakan database pada masing-masing website resminya. PICO yang digunakan dalam penelitian adalah pasien yaitu pasien DM dengan diabetic foot, intervensinya yaitu diabetic foot, komparasi tidak dilakukan pada penelitian ini, dan hasilnya yaitu cost of illness (Moher dkk., 2009; Norris dkk., 2006; Selçuk, 2019). Topik penelitian yang digunakan pada penelitian ini tidak ditemukan pada PROSPERO untuk memastikan tidak ada protokol penelitian yang sedang berlangsung untuk systematic review dengan topik yang sama.

Sebuah systematic review yang dilakukan pada tahun 2016 menyatakan bahwa cost of illness untuk pasien dengan komplikasi diabetic foot memiliki rentang biaya antara 1444 USD hingga 85718 USD dengan rata-rata biaya 10607 USD. Systematic review tersebut meneliti tentang metode cost of illness dari tiga komplikasi DM sekaligus yaitu diabetic retionopathy, diabetic renal, dan diabetic foot. Namun pada systematic review tersebut tidak dibandingkan biaya yang mana yang paling berpengaruh pada besarnya beban biaya yang dihasilkan pada systematic review tersebut dan hanya menghitung biaya yang dikeluarkan untuk pengobatan komplikasinya saja (Schirr-Bonnans dkk., 2016).

Berdasarkan penjelasan di atas maka perlu adanya penelitian mengenai cost of illness pada pasien rawat jalan DM dengan diabetic foot menggunakan systematic review. Dengan adanya penelitian ini diharapkan mampu memberikan gambaran mengenai kisaran biaya yang dikeluarkan untuk pengobatan pasien rawat jalan DM dengan diabetic foot.

\section{METODE}

\section{Jenis penelitian}

Jenis penelitian yang akan dilakukan adalah systematic literature review yaitu suatu penelitian yang dilakukan dengan cara mengidentifikasi, mengevaluasi dan menginterpretasi seluruh hasil yang relevan dengan suatu penelitian tertentu, topik tertentu, atau fenomena yang menjadi perhatian (Kitchenham, 2004). Data yang digunakan untuk penelitian ini yaitu artikel yang terkait cost of illness diabetic foot yang diambil dari beberapa database online yaitu PubMed, Cochrane, ScienceDirect, Scopus, dan Ebscohost (CINAHL). Pengambilan data yang diperlukan dilakukan secara online pada bulan April - Juli 2020. Topik penelitian yang digunakan pada penelitian ini tidak ditemukan pada PROSPERO untuk memastikan tidak ada protokol penelitian yang sedang berlangsung untuk systematic review dengan topik yang sama dan tidak dilakukan registrasi pada PROSPERO.

\section{Kata kunci}

Kata kunci yang digunakan untuk pencarian data yaitu "Burden of Disease", "Cost of Illness", "Direct Medical Cost", "Economic Burden", "Health Care Cost", dan "Healthcare Cost" serta "Diabetic Foot", "Foot Ulcer" AND diabet*, dan "Gangrene". Kata penghubung yang digunakan untuk kata kunci tersebut yaitu AND. Kata kunci tersebut didapatkan melalui perumusan PICO.

\section{Kriteria sampel}

Kriteria inklusi untuk penelitian ini yaitu studi terkait cost of illness, subyek penelitian merupakan pasien diabetic foot, dan artikel memuat hasil penelitian berupa cost dari diabetic foot. Sedangkan kriteria eksklusi dari penelitian ini yaitu artikel dengan bahasa asing selain bahasa Inggris, serta publikasi yang 
berupa systematic review, review papers/articles, conference abstract, case reports, editorials, dan letters to the editor.

\section{Pencarian dan sortir artikel}

Setelah diperoleh kata kunci yang sesuai, maka dapat dilakukan pencarian pada database yang akan digunakan melalui website resmi masing-masing database. Setelah dilakukan pencarian maka dilakukan screening pada setiap artikel yang didapatkan. Screening dilakukan melalui aplikasi EndNote X9. Pada screening tahap pertama dilakukan dengan cara memeriksa adanya duplikasi dari hasil pencarian. Setelah memisahkan artikel duplikat, dilanjutkan penyortiran. Penyortiran meliputi kesesuaian judul dan abstrak dengan topik penelitian ini, yaitu cost of illness pada penderita diabetic foot. Selanjutnya dilakukan uji eligibilitas. Pada uji eligibilitas, setiap artikel yang sudah disaring dari seleksi judul dan abstrak akan dibaca secara utuh seluruh isinya untuk melihat apakah sudah sesuai dengan kriteria inklusi yang sudah ditetapkan sebelumnya (Hermawan dkk., 2016; Moher dkk., 2009). Penyortiran dilakukan oleh satu orang dan dilakukan double check oleh dua orang lainnya. Penilaian risk of bias dari masing-masing artikel ditentukan menggunakan PRISMA checklist.

\section{Analisis data}

Data yang didapatkan dianalisa secara deskriptif dengan cara membandingkan data antar artikel yang telah disusun dalam tabel untuk mempermudah peneliti untuk menganalisa perbandingan antar artikel yang didapatkan. Biaya yang didapatkan dari artikel tersebut disesuaikan dengan menggunakan CPI (Customer Price Index) dan PPP (Purchasing Power Parities) tahun 2019 (OECD, 2020; The World Bank, 2020). Penyesuaian tersebut menggunakan rumus yaitu (Webster, 2020):

$$
\begin{aligned}
& \mathrm{PPP}=\frac{\text { biaya di negara yang dituju }}{\text { PPP tahun } 2019} \\
& \mathrm{CPI}=\frac{\text { CPI tahun yang dituju }}{\text { CPI tahun penelitian }} \times \text { biaya di tahun } \\
& \text { penelitian }
\end{aligned}
$$

Selanjutnya artikel yang memuat total biaya per bulan disesuaikan menjadi biaya per tahun untuk memudahkan analisa data dengan asumsi kejadian tersebut terjadi berulang dalam satu tahun (Ernstsson dkk., 2016).

\section{HASIL DAN PEMBAHASAN}

\section{Gambaran umum}

Artikel yang akan direview dicari melalui tiap database yang digunakan dengan keyword yang sebelumnya telah ditentukan hingga pada tanggal 22 Juli 2020. Jumlah keseluruhan artikel yang ditemukan dari lima database yang digunakan yaitu sejumlah 4702 artikel. Database yang direkomendasikan untuk digunakan dalam pencarian artikel yaitu CENTRAL (Cochrane), Medline, dan Embase jika memungkinkan (Higgins dkk., 2019). Penggambaran proses dalam melakukan review artikel tercantum pada Gambar 1.

Gambar 1. Diagram PRISMA penelitian

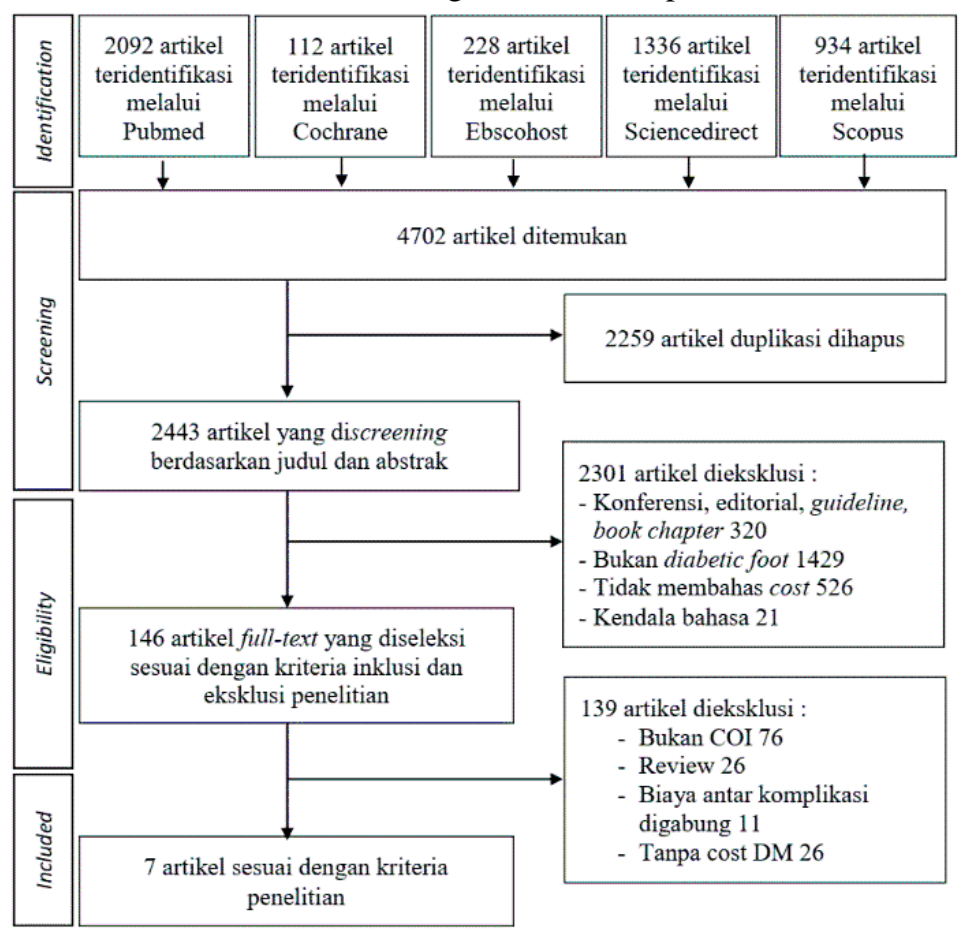


Jurnal Farmasi Dan Ilmu Kefarmasian Indonesia

Special Issue: Seminar Inovasi Teknologi Dan Digitalisasi Pada Pelayanan Kefarmasian 2020

Alasan artikel dalam kategori review dieksklusi yaitu karena review untuk sekumpulan review dikategorikan sebagai umbrella review yang prinsipnya yaitu meringkas fakta-fakta dari beberapa penelitian yang memiliki tujuan yang sama dan menghasilkan kesimpulan yang secara umum mirip antara satu sama lain. Umbrella review juga memiliki nama lain yaitu overviews of reviews, reviews of reviews, a summary of systematic reviews, dan synthesis of reviews. Tujuan dari penelitian tersebut tidak untuk mengulang penelitian dari review tersebut namun untuk menggambarkan temuan dari suatu kejadian yang spesifik karena dapat membandingkan perlakuan yang lebih luas sehingga lebih cocok untuk informasikan suatu statement dan praktik klinis dengan mempertimbangkan berbagai pilihan terapi (Aromataris dkk., 2015).

Tujuh artikel yang terpilih untuk dimasukkan ke dalam penelitian tersebut telah sesuai dengan kriteria sampel yang telah ditentukan sebelumnya. Berdasarkan Scimago, jurnal yang digunakan dalam penelitian ini termasuk dalam Q2 dan Q3 sehingga yang artinya jurnal yang digunakan cukup berkualitas untuk dimasukkan ke dalam penelitian dengan risk of bias antara moderate hingga high.

\section{Karakteristik studi}

Dari tujuh artikel yang didapatkan tersebut, data yang diperlukan untuk menganalisis data diletakkan pada satu tabel untuk memudahkan peneliti untuk membandingkan data antar artikel tersebut. Dari tabel tersebut diketahui bahwa perspektif yang banyak digunakan yaitu perspektif rumah sakit. Hal ini dapat disebabkan karena dengan digunakannya perspektif tersebut maka hasil penelitian tersebut dapat menjadi salah satu pertimbangan bagi para pembuat kebijakan dalam pemerataan dana kesehatan dan pemilihan pengobatan yang efektif khususnya untuk pasien DM dengan diabetic foot. Selain itu, mayoritas metode yang digunakan untuk mengambil data penelitian yaitu dengan cara retrospektif dan bottom-up. Hal ini dapat disebabkan karena dengan digunakannya metode pengambilan data secara retrospektif maka waktu yang digunakan untuk penelitian lebih cepat untuk diselesaikan dan mengurangi risiko pasien yang mengundurkan diri di tengah penelitian karena data yang diambil adalah data rekam medis pasien yang menjalani pengobatan sesuai waktu yang ditentukan oleh peneliti.
Mayoritas negara yang meneliti tentang cost of illness yaitu Nigeria dan Turki. Kedua negara tersebut tergabung dalam kelompok Developing Eight (D-8) yaitu suatu kelompok yang terdiri dari delapan negara berkembang yang bertujuan untuk meningkatkan kesejahteraan masyarakat negara anggotanya melalui pembangunan ekonomi dan sosial (Kemenlu RI, 2014). Negara-negara berkembang banyak menghadapi tantangan dalam membangun sistem kesehatan yang kuat dan handal, salah satunya dalam pembiayaan kesehatan meliputi pemerataan dan akses pelayananan kesehatan yang berkualitas (Putri, 2019).

Besar sampel dari setiap penelitian bervariasi mulai dari yang terkecil sebanyak 20 pasien hingga yang terbesar sebanyak 138 pasien. Pada penelitian Ogbera dkk. (2006), sampel pasien yang diambil hanya 20 pasien karena menurut data terdapat 97 pasien yang masuk rrumah sakit akitbat diabetic foot dan menurut Gay dkk. (2009), sampel untuk populasi yang relatif kecil dapat digunakan minimal $20 \%$ dari jumlah populasi sehingga jumlah sampel 20 pasien untuk 97 pasien populasi dapat digunakan pada penelitian tersebut (Gay dkk., 2009; Ogbera dkk., 2006). Secara umum dikatakan bahwa semakin besar sampel maka semakin besar kemungkinan hasilnya akan semakin baik karena dapat mencerminkan populasi. Dengan sampel yang besar, mean dan standar deviasi yang diperoleh mempunyai probabilitas yang tinggi untuk menyerupai mean dan standar deviasi populasi. Meskipun demikian, sampel yang kecil bila dipilih secara acak dapat mencerminkan populasi secara akurat (Alwi, 2015). Biaya yang dikeluarkan pada tiap negara dapat berbeda tergantung dari kebijakan dari para pembuat kebijakan di negara tersebut sehingga perlu dilakukan penelitian beban biaya pada masingmasing negara untuk mendapatkan jumlah total beban biaya yang pasti untuk suatu penyakit tertentu.

Berdasarkan systematic review sebelumnya, metode yang banyak digunakan yaitu retrospektif dan bottom-up. Hal tersebut sama dengan yang ditemukan dalam penelitian ini. Sedangkan perspektif yang paling banyak digunakan yaitu pembayar pihak ketiga dan negara yang paling banyak muncul adalah Amerika Serikat, berbeda dengan hasil penelitian ini. Hal tersebut dapat diakibatkan oleh perbedaan database dan kata kunci yang digunakan untuk pencarian artikel (Schirr-Bonnans dkk., 2016). 
Tabel 1. Tabel data systematic review diabetic foot

\begin{tabular}{|c|c|c|c|c|c|c|c|c|}
\hline No. & Pengarang, Tahun & Perspektif & $\begin{array}{c}\text { Metode Pengambilan } \\
\text { Data }\end{array}$ & Negara & Tempat Penelitian & Waktu Penelitian & $\begin{array}{c}\text { Besar } \\
\text { Sampel }\end{array}$ & Kriteria Pasien \\
\hline 1. & $\begin{array}{c}\text { (Shobhana dkk., } \\
\text { 2000) }\end{array}$ & Pasien & $\begin{array}{l}\text { Cross sectional, } \\
\text { bottom-up }\end{array}$ & India & $\begin{array}{l}\text { The Diabetes Research } \\
\text { Centure and MV Hospital for } \\
\text { Diabetes, Chennai }\end{array}$ & 2001 & 106 pasien & $\begin{array}{l}\text { Rawat inap dan } \\
\text { rawat jalan }\end{array}$ \\
\hline 2. & (Ogbera dkk., 2006) & Rumah sakit & $\begin{array}{l}\text { Retrospektif, bottom- } \\
\text { up }\end{array}$ & Nigeria & $\begin{array}{l}\text { Lagos University Teaching } \\
\text { Hospital (LUTH) }\end{array}$ & $2002-2003$ & 20 pasien & Rawat inap \\
\hline 3. & $\begin{array}{l}\text { (Keskek dkk., } \\
\text { 2014) }\end{array}$ & $\begin{array}{l}\text { Pembayar } \\
\text { pihak ketiga }\end{array}$ & $\begin{array}{l}\text { Retrospektif, bottom- } \\
\text { up }\end{array}$ & Turki & $\begin{array}{l}\text { Internal Medicine Clinic of } \\
\text { Adana Numune Training and } \\
\text { Research Hospital }\end{array}$ & $2010-2012$ & 91 pasien & Rawat inap \\
\hline 4. & $\begin{array}{l}\text { (Danmusa dkk., } \\
\text { 2016) }\end{array}$ & Rumah sakit & $\begin{array}{l}\text { Retrospektif, bottom- } \\
\text { up }\end{array}$ & Nigeria & $\begin{array}{l}\text { Ahmadu Bello University } \\
\text { Teaching Hospital (ABUTH) }\end{array}$ & Januari - Juni 2014 & 94 pasien & Rawat inap \\
\hline 5. & $\begin{array}{c}\text { (Karagöz dkk., } \\
\text { 2016) }\end{array}$ & Rumah sakit & $\begin{array}{l}\text { Retrospektif, bottom- } \\
\text { up }\end{array}$ & Turki & $\begin{array}{l}\text { Umraniye Training and } \\
\text { Research Hospital }\end{array}$ & $\begin{array}{l}1 \text { Januari } 2012- \\
31 \text { Desember } 2015\end{array}$ & 138 pasien & Rawat inap \\
\hline 6. & (Oksuz dkk., 2016) & $\begin{array}{l}\text { Pembayar } \\
\text { pihak ketiga }\end{array}$ & $\begin{array}{l}\text { Prevalence-based, } \\
\text { bottom-up }\end{array}$ & Turki & Turki & 2014 & $\begin{array}{l}\text { Tidak } \\
\text { disebutkan }\end{array}$ & $\begin{array}{l}\text { Rawat inap dan } \\
\text { rawat jalan }\end{array}$ \\
\hline 7. & $\begin{array}{l}\text { (Muhammad dkk., } \\
\text { 2018) }\end{array}$ & Pasien & $\begin{array}{l}\text { Cross sectional, } \\
\text { bottom-up }\end{array}$ & Nigeria & $\begin{array}{l}\text { Tiga Rumah Sakit di } \\
\text { Northwestern Nigeria }\end{array}$ & $\begin{array}{l}\text { Oktober } 2014- \\
\text { September } 2015\end{array}$ & 90 pasien & $\begin{array}{l}\text { Rawat inap dan } \\
\text { rawat jalan }\end{array}$ \\
\hline
\end{tabular}




\section{Komponen Biaya}

Biaya yang didapatkan dari hasil artikel yang terpilih dituliskan dalam biaya rata-rata (mean cost) yang terdiri dari biaya langsung (direct cost) dan biaya tidak langsung (indirect cost). Biaya tersebut telah diubah dari mata uang dari negara masing-masing menjadi USD menggunakan CPI dan PPP tahun 2019 seperti yang telah tercantum pada Tabel 2 (OECD,
2020; The World Bank, 2020). PPP digunakan untuk menyamakan daya beli mata uang yang berbeda dengan menyamakan tingkat harga anta negara yang dihitung dalam USD (OECD, 2020). Sedangkan CPI digunakan untuk menyamakan perubahan harga suatu barang atau jasa yang dibayarkan konsumen dari waktu ke waktu (BLS, 2020).

Tabel 2. Tabel konversi biaya per pasien

\begin{tabular}{|c|c|c|c|c|c|c|}
\hline No. & $\begin{array}{c}\text { Pengarang, } \\
\text { Tahun }\end{array}$ & Negara & Mean cost & PPP (USD) & CPI (USD) & $\begin{array}{c}\text { Hasil Mean Cost } \\
\text { (USD) }\end{array}$ \\
\hline 1. & $\begin{array}{c}\text { (Shobhana } \\
\text { dkk., 2000) }\end{array}$ & India & Rs $15450 /$ tahun & 731,98/tahun & 2341,63/tahun & 2341,63/tahun \\
\hline 2. & $\begin{array}{c}\text { (Ogbera dkk., } \\
2015)\end{array}$ & Nigeria & $\begin{array}{c}\text { NGN } \\
186513,3 / \text { episode }\end{array}$ & $1376,47 /$ episode & $8129,96 /$ episode & $8129,96 /$ episode \\
\hline 3. & $\begin{array}{c}\text { (Keskek dkk., } \\
\text { 2014) }\end{array}$ & Turki & S976,1/episode & 1060,40/episode & 2144,21/episode & 2144,2 /episode \\
\hline 4. & $\begin{array}{c}\text { (Danmusa } \\
\text { dkk., 2016) }\end{array}$ & Nigeria & $\begin{array}{l}\$ 556 / 6 \text { bulan } \\
\$ 1104 / 6 \text { bulan } \\
\$ 1808 / 6 \text { bulan }\end{array}$ & $\begin{array}{l}738,59 / 6 \text { bulan } \\
1466,56 / 6 \text { bulan } \\
2401,75 / 6 \text { bulan }\end{array}$ & $\begin{array}{l}1351,62 / 6 \text { bulan } \\
2683,80 / 6 \text { bulan } \\
4395,20 / 6 \text { bulan }\end{array}$ & $\begin{array}{l}\text { 2703,24/tahun } \\
5367,60 / \text { tahun } \\
8790,41 / \text { tahun }\end{array}$ \\
\hline 5. & $\begin{array}{c}\text { (Karagöz dkk., } \\
\text { 2016) }\end{array}$ & Turki & \$2880/tahun & $3148,19 /$ tahun & 5052,80 /tahun & $7379,35 /$ tahun \\
\hline 6. & $\begin{array}{l}\text { (Oksuz dkk., } \\
\text { 2016) }\end{array}$ & Turki & $\$ 14287,7 /$ tahun & $8575,72 /$ tahun & $14819,78 /$ tahun & $14819,78 /$ tahun \\
\hline 7. & $\begin{array}{l}\text { (Muhammad } \\
\text { dkk., 2018) }\end{array}$ & Nigeria & $\$ 140735,56 /$ bulan & 1038,63/bulan & 1748,13/bulan & 20977,56/tahun \\
\hline
\end{tabular}

Dari hasil yang ada pada Tabel 3, total beban biaya yang dihasilkan bervariasi jumlahnya 2341,63 USD/tahun hingga 20977,56 USD/tahun untuk perspektif pasien, 2703,24 USD/tahun hingga 8790,41 USD/tahun dan 8129,96 USD/episode untuk perspektif rumah sakit, serta 2144,21 USD/episode dan 14819,78 USD/tahun untuk perspektif pembayar pihak ketiga. Biaya episode yang disebutka juga bervariasi antara dua minggu hingga dua bulan per episode. Beban biaya yang paling besar dihabiskan oleh direct medical cost yaitu mencapai 51,7\% hingga 98,4\% dari total keseluruhan biaya yang dikeluarkan untuk pengobatan pasien DM dengan diabetic foot. Rentang yang cukup lebar tersebut dapat diakibatkan karena komponen yang dihitung antar artikel berbeda-beda. Pada systematic review sebelumnya pada tahun 2016, cost of illness untuk pasien dengan komplikasi diabetic foot yaitu memiliki rentang biaya antara 1444 USD hingga 85718 USD dengan rata-rata biaya 10607 menggunakan perspektif pasien, masyarakat, dan pembayar pihak ketiga (Schirr-Bonnans dkk., 2016).

Pada artikel milik Shobhana dkk. (2000), biaya yang dihitung hanya direct cost sedangkan untuk indirect cost dan intangible cost tidak dihitung meskipun perspektif yang digunakan adalah perspektif pasien sehingga biaya yang dihasilkan memiliki perbandingan yang cukup jauh jika dibandingkan dengan hasil dari artikel lain dengan total biaya per tahun. Hal ini diakibatkan juga oleh biaya tindakan dan terapi dalam artikel tersebut yang cukup kecil karena kebanyakan dari pasien yang diambil memiliki latar belakang ekonomi yang rendah sehingga lebih memilih untuk tidak mengambil tindakan operasi untuk mengobati penyakitnya (Shobhana dkk., 2000).

Pada artikel milik Muhammad dkk., juga dikatakan bahwa perbedaan hasil yang didapatkan dibandingkan dengan artikel lain dapat diakibatkan oleh perbedaan sistem kesehatan untuk menangani diabetic foot ini seperti digunakannya mesin berteknologi tinggi untuk diagnosis dan pengobatan pasien sehingga menghasilkan biaya yang lebih tinggi daripada lainnya. Selain itu pada artikel ini juga disebutkan bahwa mayoritas masyarakat lebih memilih menggunakan obat tradisional dan obat yang diresepkan oleh dokter karena tidak mampu untuk membayar biaya untuk operasi sehingga berakibat pada memburuknya kondisi pasien dan membuat pasien harus tetap dioperasi. Mayoritas pasien juga harus tetap dirawat di rumah sakit lebih lama daripada yang seharusnya setelah menjalani operasi karena memiliki 
Special Issue: Seminar Inovasi Teknologi Dan Digitalisasi Pada Pelayanan Kefarmasian 2020

tempat tinggal yang jauh dari fasilitas kesehatan yang mengakibatkan sulitnya tenaga kesehatan untuk melakukan follow up pada pasien sehingga menyebabkan beban biaya yang dihasilkan semakin besar. Serta pasien yang dirawat umumnya merupakan laki-laki yang berstatus pekerja aktif sehingga berdampak pada besarnya biaya penurunan produktivitas pasien, bahkan beberapa diantaranya harus keluar dari pekerjaannya dan mencari pekerjaan lain (Muhammad dkk., 2018).

Tabel 3. Tabel cost DM dengan diabetic foot per pasien

\begin{tabular}{|c|c|c|c|c|c|c|}
\hline \multirow{2}{*}{ No. } & \multirow{2}{*}{$\begin{array}{c}\text { Pengarang, } \\
\text { Tahun }\end{array}$} & \multirow{2}{*}{$\begin{array}{l}\text { Mean cost } \\
\text { (USD) }\end{array}$} & \multicolumn{2}{|c|}{ Direct cost (USD) } & \multirow{2}{*}{$\begin{array}{l}\text { Indirect cost } \\
\text { (USD) }\end{array}$} & \multirow{2}{*}{$\begin{array}{c}\text { Intangible } \\
\text { costs (USD }\end{array}$} \\
\hline & & & Medical & Nonmedical & & \\
\hline 1. & $\begin{array}{c}\text { (Shobhana dkk., } \\
\text { 2000) }\end{array}$ & 2341,63/tahun & $\begin{array}{c}2188,99 / \text { tahun } \\
(98,4 \%)\end{array}$ & $\begin{array}{c}37,15 / \text { tahun } \\
(1,6 \%)\end{array}$ & - & - \\
\hline 2. & $\begin{array}{c}\text { (Ogbera dkk., } \\
\text { 2006) }\end{array}$ & $3682,06 /$ episode & $3682,06 /$ episode & (1), & - & - \\
\hline \multirow[t]{2}{*}{3.} & $\begin{array}{c}\text { (Keskek dkk., } \\
\text { 2014) }\end{array}$ & $2144,21 /$ episode & $2144,21 /$ episode & - & - & - \\
\hline & & $\begin{array}{l}\text { 2703,24/tahun } \\
\quad \text { (Grade 2) }\end{array}$ & $\begin{array}{l}\text { 2703,24/tahun } \\
\quad \text { (Grade 2) }\end{array}$ & - & - & - \\
\hline \multirow[t]{2}{*}{4.} & $\begin{array}{c}\text { (Danmusa dkk., } \\
\text { 2016) }\end{array}$ & $\begin{array}{l}\text { 5367,60/tahun } \\
\text { (Grade 3) }\end{array}$ & $\begin{array}{l}\text { 5367,60/tahun } \\
\text { (Grade 3) }\end{array}$ & - & - & - \\
\hline & & $\begin{array}{l}\text { 8790,41/tahun } \\
\text { (Grade 4) }\end{array}$ & $\begin{array}{l}\text { 8790,41/tahun } \\
\text { (Grade 4) }\end{array}$ & - & - & - \\
\hline 5. & $\begin{array}{c}\text { (Karagöz dkk., } \\
\text { 2016) }\end{array}$ & 7379,35/tahun & 7379,35/tahun & - & - & - \\
\hline 6. & $\begin{array}{c}\text { (Oksuz dkk., } \\
\text { 2016) }\end{array}$ & $21447,66 /$ tahun & $21447,66 /$ tahun & - & - & - \\
\hline 7. & $\begin{array}{l}\text { (Muhammad } \\
\text { dkk., 2018) }\end{array}$ & $20977,56 /$ tahun & $\begin{array}{c}10815,62 / \text { tahun } \\
(51,7 \%)\end{array}$ & $\begin{array}{c}5216,76 / \text { tahun } \\
(24,9 \%)\end{array}$ & $\begin{array}{c}4909,8 / \text { tahun } \\
(23,4 \%)\end{array}$ & - \\
\hline
\end{tabular}

Biaya yang terhitung tersebut terdiri dari bermacam-macam komponen sesuai dengan biaya apa saja yang diteliti oleh para peneliti pada tiap artikel yang terpilih. Biaya yang dikeluarkan untuk obatobatan yang dikonsumsi oleh pasien dihitung oleh semua peneliti pada tiap artikel. Biaya tindakan dan terapi juga dihitung oleh semua peneliti pada tiap artikel terpilih. Biaya yang termasuk tindakan dan terapi ini yaitu seperti biaya pembedahan, biaya amputasi, biaya pembalutan luka, biaya fisioterapi, terapi oksigen, debridement, revaskularisasi, dan lainlain. Biaya pemeriksaan dokter termasuk untuk keperluan diagnosis dan monitoring perkembangan pasien, dokter bedah, dokter ortopedi, dokter dermatologi, fisioterapis, dan tenaga kesehatan lainnya. Lalu biaya laboratorium yang dimaksud termasuk gula darah, radiologi, mikrobiologi, patologi, dan tes lab lainnya. Biaya fasilitas rumah sakit termasuk biaya kamar/tempat tidur, biaya akomodasi yang disediakan oleh pihak rumah sakit untuk pasien dan keluarga pasien, dan fasilitas lainnya. Lalu untuk pasien yang sedang dirawat jalan juga dikenakan biaya konsumsi untuk makan saat di rawat inap, dan biaya transportasi ke rumah sakit. Sedangkan untuk indirect cost yaitu biaya penurunan produktivitas akibat pasien yang sakit sehingga tidak dapat bekerja serta biaya untuk caregiver. Tidak ada artikel yang masuk ke dalam penelitian ini membahas intangible cost. Intangible cost dihitung pada perspektif pasien dan societal namun dua artikel yang menghitung biaya dengan perspektif pasien tidak memperhitungkan biaya tersebut. Intangible cost tidak diperhitungkan dalam penelitian cost of illness akibat kesulitan dalam pengukuran nilai uang pada tipe biaya tersebut (Muhammad dkk., 2018; Rascati, 2014; Shobhana dkk., 2000). Rincian komponen cost yang dihitung dalam setiap artikel penelitian per pasien tercantum pada Tabel 4.

Dari hasil yang ditemukan dua artikel yang memuat hasil antara cost DM dengan diabetic foot yang dibandingkan dengan cost DM tanpa komplikasi diabetic foot. Menurut Shobana dkk. (2001), hasilnya biaya pengobatan yang dihabiskan oleh pasien DM dengan diabetic foot ini hampir empat kali lipat lebih besar daripada pasien tanpa diabetic foot. Biaya untuk komplikasi diabetic foot sendiri setelah dihitung dari selisih hasil penelitian tersebut yaitu 1678,65 USD yang menghabiskan $71,7 \%$ biaya yang dikeluarkan untuk pengobatan DM dengan diabetic foot (Shobhana dkk., 2000). Sedangkan menurut Keskek dkk. (2014), 
total biaya yang dihabiskan pasien DM dengan diabetic foot mencapai lebih dari dua kali lipat lebih banyak daripada biaya pengobatan biaya yang dihabiskan untuk pengobatan DM tanpa komplikasi. Sehingga biaya untuk komplikasi diabetic foot yaitu 1199,93 USD atau sebesar 55,9\% dari total pengeluran untuk biaya pengobatan pasien DM dengan diabetic foot (Keskek dkk., 2014). Perbedaan biaya kedua artikel tersebut dapat disebabkan oleh perbedaan perspektif yang dihitung sehingga biaya yang diperhitungkan pada tiap artikel tersebut berbeda. Selain itu, perbedaan tersebut juga diakibatkan oleh adanya perbedaan perhitungan biaya. Pada penelitian milik Shobana digunakan perhitungan tahun sedangkan Keskek (2014) menghitung biaya per episode yang rata-rata episodenya yaitu dua minggu. Perbedaan komponen cost yang dihitung untuk artikel yang memuat DM dengan diabetic foot dan tanpa diabetic foot teeerdapat pada Tabel 5.

Keterbatasan dari penelitian ini yaitu adanya keterbatasan sumber daya sehingga tidak semua database dapat digunakan, seperti EMBASE sehingga tidak dapat digunakan dalam penelitian.

Tabel 4. Rincian komponen cost yang dihitung dalam artikel penelitian per pasien

\begin{tabular}{|c|c|c|c|c|c|c|c|c|c|c|c|c|}
\hline \multirow{3}{*}{ No. } & \multirow{3}{*}{ Pengarang, Tahun } & \multirow{3}{*}{$\mathrm{P}$} & \multicolumn{7}{|c|}{ Direct Cost } & \multirow{2}{*}{\multicolumn{2}{|c|}{ Indirect Cost }} & \multirow{3}{*}{$\begin{array}{c}\text { Intangible } \\
\text { Cost }\end{array}$} \\
\hline & & & \multicolumn{5}{|c|}{ Medical } & \multicolumn{2}{|c|}{ Nonmedical } & & & \\
\hline & & & $\mathrm{O}$ & $\mathrm{Ti}$ & $\mathrm{D}$ & $\mathrm{L}$ & $\mathrm{F}$ & $\mathrm{K}$ & $\mathrm{Tr}$ & PP & $\mathrm{C}$ & \\
\hline 1. & (Shobhana dkk., 2000) & Ps & $\sqrt{ }$ & $\sqrt{ }$ & $\sqrt{ }$ & $\sqrt{ }$ & $\sqrt{ }$ & - & $\sqrt{ }$ & - & - & - \\
\hline 2. & (Ogbera dkk., 2006) & $\mathrm{RS}$ & $\sqrt{ }$ & $\sqrt{ }$ & - & $\sqrt{ }$ & $\sqrt{ }$ & - & - & - & - & - \\
\hline 3. & (Keskek dkk., 2014) & PK & $\sqrt{ }$ & $\sqrt{ }$ & - & $\sqrt{ }$ & $\sqrt{ }$ & - & - & - & - & - \\
\hline 4. & (Danmusa dkk., 2016) & RS & $\sqrt{ }$ & $\sqrt{ }$ & $\sqrt{ }$ & $\sqrt{ }$ & $\sqrt{ }$ & - & - & - & - & - \\
\hline 5. & (Karagöz dkk., 2016) & $\mathrm{RS}$ & $\sqrt{ }$ & $\sqrt{ }$ & $\sqrt{ }$ & $\sqrt{ }$ & $\sqrt{ }$ & - & - & - & - & - \\
\hline 6. & (Oksuz dkk., 2016) & $\mathrm{PK}$ & $\sqrt{ }$ & $\sqrt{ }$ & $\sqrt{ }$ & $\sqrt{ }$ & $\sqrt{ }$ & - & - & - & - & - \\
\hline 7. & (Muhammad dkk., 2018) & Ps & $\sqrt{ }$ & $\sqrt{ }$ & $\sqrt{ }$ & $\sqrt{ }$ & $\sqrt{ }$ & $\sqrt{ }$ & $\sqrt{ }$ & $\sqrt{ }$ & $\sqrt{ }$ & - \\
\hline
\end{tabular}

Keterangan:

O: Biaya Obat

Ti: Biaya Tindakan dan Terapi

D: Biaya Pemeriksaan Dokter

L: Biaya Laboratorium

F: Biaya Fasilitas Rumah Sakit

P: Perspektif

Ps: Pasien

$\sqrt{ }$ : biaya yang ikut diteliti

\author{
K: Biaya Konsumsi \\ Tr: Biaya Transportasi \\ PP: Biaya Penurunan Produktivitas \\ C: Biaya Caregiver \\ RS: Rumah Sakit \\ PK: Pembayar Pihak Ketiga \\ -: Biaya tidak diteliti
}

Tabel 5. Tabel cost DM dengan diabetic foot dan tanpa diabetic foot per pasien

\begin{tabular}{lcccc}
\hline \multirow{2}{*}{ Komponen Cost } & \multicolumn{2}{c}{ (Shobhana dkk., 2000) } & (Keskek dkk., 2014) \\
\cline { 2 - 5 } & Tanpa diabetic & Dengan diabetic & Tanpa diabetic foot & $\begin{array}{c}\text { Dengan diabetic } \\
\text { foot }\end{array}$ \\
\hline Biaya pemeriksaan dokter & foot & $\sqrt{ }$ & $\sqrt{ }$ & - \\
Biaya spesialis & $\sqrt{ }$ & $\sqrt{ }$ & - \\
Biaya operasi & - & $\sqrt{ }$ & $\sqrt{ }$ \\
Biaya rawat inap & - & $\sqrt{ }$ & $\sqrt{ }$ \\
Biaya laboratorium & $\sqrt{ }$ & $\sqrt{ }$ & - \\
Biaya pengobatan & $\sqrt{ }$ & - & 2144,21 \\
Biaya alas kaki & - & $\sqrt{ }$ & USD/episode \\
Biaya transportasi & $\sqrt{ }$ & 2341,63 & 944,28 & USD/episode \\
Total Biaya & 662,98 & USD/tahun & 1199,93 USD/episode (55,9\%) \\
\hline Biaya Komplikasi & USD/tahun & \multicolumn{2}{c}{} \\
\hline
\end{tabular}

\section{KESIMPULAN}

Pasien DM dengan diabetic foot menghabiskan lebih banyak sumber daya sehingga meningkatkan biaya pengobatan dibandingkan dengan DM tanpa diabetic foot.

\section{UCAPAN TERIMAKASIH}

Artikel ini telah dipaparkan pada kegiatan seminar nasional dan temu ilmiah di Fakultas Farmasi Universitas Airlangga tanggal 26 September 2020. 
Jurnal Farmasi Dan Ilmu Kefarmasian Indonesia

\section{DAFTAR PUSTAKA}

ADA. (2019). Standards of Medical Care in Diabetes 2019. Diabetes Care; 42; S1-S187.

Alwi, I. (2015). Kriteria Empirik dalam Menentukan Ukuran Sampel. Jurnal Formatif; 2; 140-148.

Aromataris, E., Fernandez, R., Godfrey, C. M., Holly, C., Khalil, H. \& Tungpunkom, P. (2015). Summarizing Systematic Reviews: Methodological Development, Conduct And Reporting of an Umbrella Review Approach. International Journal of Evidence-Based Healthcare; 13; 132-140.

Balasegaran, M. (2006). Wabah Diabetes Ancam Asia. https://bbc.co.uk/indonesian/indepth/story/2006/ 02/printable/060222_diabetesinasia.shtml.

Accessed: 23 Desember 2019.

BLS. (2020). Customer Price Index. https://ww.bls.gov/cpi/questions-and-

answers.htm. Accessed: 4 September 2020.

Danmusa, U. M., Terhile, I., Nasir, I. A., Ahmad, A. A. \& Muhammad, H. Y. (2016). Prevalence and Healthcare Costs Associated with The Management of Diabetic Foot Ulcer in Patients Attending Ahmadu Bello University Teaching Hospital, Nigeria. International Journal of Health Sciences, Qassim University; 10; 219 228.

Ernstsson, O., Gyllensten, H., Alexandeson, K., Tinghog, P., Friberg, E. \& Norlund, A. (2016). Cost of Illness of Multiple Sclerosis - a Systematic Review. PLoS ONE, 11; e0159129.

Gay, L., Mills, G. E. \& Airasian, P. (2009). Educational Research, Competencies for Analysis and Application. New Jersey: Pearson Education, Inc.

Hermawan, L., Bellaniar, M., \& Kristoforus, J. (2016). Analisis Laporan Skripsi dengan Metoda Systematic Literature Review. Palembang: Universitas Katolik Musi Charitas.

Higgins, J., Thomas, J., Chandler, J., Cumptons, M., Li, T., Page, M. \& Welch, V. (2019). Cochrane Handbook for Systematic Reviews of Interventions. London: The Cochrane Collaboration.

IDF. (2017). IDF Diabetes Atlas (Eighth Ed). Brussel: International Diabetes Federation.

INFID. (2017). Sustainable Development Goals. https://www.sdg2030indonesia.org. Accessed: 15 November 2019.

Karagöz, G., Kadanal, A., Öztürk, S., Öztürk, S.,
Çakar, Ş. E., Çomo, Ş. \& Do, F. (2016). The Analysis of the Cost and Amputation Rates of Hospitalized Diabetic Foot Infection Patients. International Journal of Diabetes in Developing Countries; 37; 201-205.

Kemenkes RI. (2018). Hasil Utama Riskesdas 2018. Jakarta: Kemenkes RI.

Kemenlu RI. (2014). Developing Eight (D-8). https://kemlu.go.id/portal/id/read/143/halaman_1 ist_lainnya/developing-eight-d-8. Accessed: 16 Agustus 2020

Keskek, S. O., Kirim, S. \& Yanmaz, N. (2014). Estimated Costs of The Treatment of Diabetic Foot Ulcers in A Tertiary Hospital in Turkey. Pakistan Journal of Medical Sciences; 30(5); 968-971.

Kitchenham, B. (2004). Procedures for Performing Systematic Reviews. Keele: Keele University.

Langi, Y. A. (2013). Penatalaksanaan Ulkus Kaki Diabetes Secara Terpadu. Jurnal Biomedik; 3; 95-101.

Martono, N. (2012). Metode Penelitian Kuantitatif: Analisis dan Analisis Data Sekunder. Jakarta: PT Raja Grafindo Persada.

Moher, D., Liberati, A. \& Aitman, D. (2009). Preferred Reporting Items for Systematic Reviews and Meta-Analyses: The PRISMA Statement. PLoS Med, 6; e1000097.

Muhammad, F. Y., Pedro, L. M., Suleiman, H. H., Uloko, A. E., Gezawa, I. D., Adenike, E., Ramalan, M. \& Iliyasu, G. (2018). Cost of Illness of Diabetic Foot Ulcer in a Resource Limited Setting: A Study from Northwestern Nigeria. Journal of Diabetes \& Metabolic Disorders; 17; 93-99.

Norris, K. P., Johnson, C. J., Anderson Jr, G. \& Byant, P. J. (2006). Literature Evaluation II : Beyond the Basics. New York: McGraw Hil.

OECD. (2020). Purchasing Power Parities (PPP). https://data.oecd.org/conversion/purchasingpower-parities-ppp.htm. Accessed: 22 Agustus 2020.

Ogbera, A. O., Fasanmade, O., Ohwovoriole, A. E. \& Adediran, O. (2006). An Assessment of the Disease Burden of Foot Ulcers in Patients with Diabetes Mellitus Attending a Teaching Hospital in Lagos, Nigeria. Lower Extremity Wound; 5; 244-249.

Oksuz, E., Malhan, S., Sonmez, B. \& Tekin, R. N. (2016). Cost of Illness Among Patients with 
Jurnal Farmasi Dan Ilmu Kefarmasian Indonesia

Special Issue: Seminar Inovasi Teknologi Dan Digitalisasi Pada Pelayanan Kefarmasian 2020

Diabetic Foot Ulcer In Turkey. World Journal of Diabetes; 7; 462-469.

PERKENI. (2015). Konsensus Pengelolaan dan Pencegahan Diabetes Mellitus Tipe 2 di Indonesia 2015. Jakarta: Perkeni.

Putri, R. N. (2019). Perbandingan Sistem Kesehatan di Negara Berkembang dan Negara Maju. Jurnal Ilmiah Universitas Batanghari Jambi; 19; 139146.

Raghav, A., Khan, Z. A., Labala, R. K., Mishra, J. A., Noor, S. \& Kumar, B. (2018). Financial Burden of Diabetic Foot Ulcers to World: a Progressive Topic to Discuss Always. Therapeutic Advances in Endocrinology and Metabolism; 9; 29-31.

Rascati, K. L. (2014). Essentials of Pharmacoeconomics (Second Ed). Philadelphia: Lippincott Williams \& Wilkins.

Schirr-Bonnans, S., Costa, N., Derumeaux-Burel, H., Bos, J., Lepage, B., Garnault, V., Martini, J., Hanaire, H., Turnin, M. C. \& Molinier, L. (2016). Cost of Diabetic Eye, Renal and Foot Complications: a Methodological Review. European Journal of Health Economics; 18; 293-312

Schwinghammer, T. L. (2015). Endocrinologic disorders. New York: Mc Graw Hill Medical.

Selçuk, A. A. (2019). A Guide for Systematic Reviews: PRISMA. Turkish Archives of Otorhinolaryngology; 57; 57-58.

Shobhana, R., Rama Rao, P., Lavanya, A., Vijay, V. \& Ramachandran, A. (2000). Cost Burden to
Diabetic Patients with Foot Complications - A Study from Southern India. Journal of the Association of Physicians of India; 48; 11471150.

Singh, S., Pai, D. L. \& Yuhhui, C. (2013). Diabetic Foot Ulcer - Diagnosis and Management. Clinical Research on Foot \& Ankle; 1; 1-9.

The World Bank. (2020). Consumer Price Index. https://data.worldbank.org/indicator/FP.CP.TOT L?end=2019\&name_desc $=$ false \&start $=1960 \& v i$ ew=chart. Accessed: 22 Agustus 2020

Triplitt, C. L., Reasner, C. A. \& Isley, W. L. 2016. Endocrinologic Disorders: Diabetes Mellitus. New York: Mc Graw Hill Medical.

Webster, I. (2020). Inflation Rate between 1800 - 2020: Inflation

Calculator. https://www.officialdata.org/us/inflation/1800?a mount=1. Accessed: 22 Agustus 2020.

WHO. (2018). Global Report on Diabetes. Geneva: World Health Organization.

Yusuf, S., Okuwa, M., Irwan, M., Rassa, S., Laitung, B., Thalib, A., Kasim, S., Sanada, H., Nakatani, T. \& Sugama, J. (2016). Prevalence and Risk Factor of Diabetic Foot Ulcers in a Regional Hospital, Eastern Indonesia. Open Journal of Nursing; 6; 1-10.

Zhang, P., Lu, J., Jing, Y., Tang, S., Zhu, D. \& Bi, Y. (2017). Global Epidemiology of Diabetic Foot Ulceration: A Systematic Review and MetaAnalysis $\dagger$. Annals of Medicine; 49; 106-116. 